Bentham open
CrossMark
Content list available at: www.benthamopen.com/TOMCJ/
DOI: $10.2174 / 1874104501711010024$

RESEARCH ARTICLE

\title{
Tacrine, Trolox and Tryptoline as Lead Compounds for the Design and Synthesis of Multi-target Agents for Alzheimer's Disease Therapy
}

\author{
Gerard A. K. Teponnou, Jacques Joubert and Sarel F. Malan* \\ Pharmaceutical Chemistry, School of Pharmacy, University of the Western Cape, Private Bag X17, Bellville 7535, \\ South Africa
}

\begin{abstract}
The versatile biological activities of tacrine, trolox and $\beta$-carboline derivatives make them promising lead structures for the development of multifunctional Alzheimer's disease (AD) agents. Based on the topology of the active site of cholinesterases and other target proteins involved in the pathogenesis of $\mathrm{AD}$, we have designed and synthesized tacrine-trolox and tacrine-tryptoline hybrids with various linker chain lengths. The hybrids containing the trolox moiety (8a-8d) showed moderate to high $T c \mathrm{AChE}$ inhibition $\left(\mathrm{IC}_{50}: 17.37-2200 \mathrm{nM}\right)$, eqBuChE inhibition $\left(\mathrm{IC}_{50}: 3.16-128.82 \mathrm{nM}\right)$ and free radical scavenging activities $\left(\mathrm{IC}_{50}: 11.48-\right.$ $49.23 \mu \mathrm{M})$. The hybrids with longer linker chain lengths in general showed better ChE inhibitory activity. As expected, free radical scavenging activities were not significantly affected by varying linker chain lengths. The hybrid compound containing the tryptoline moiety linked with a 7 carbon spacer to tacrine (14) displayed the best AChE and BuChE inhibitory activity $\left(\mathrm{IC}_{50}=17.37\right.$ and 3.16 $\mathrm{nM}$ ). Docking experiments exhibited that compounds $\mathbf{8 d}$ and $\mathbf{1 4}$ were able to bind to both the CAS and PAS of TcAChE and eqBuChE, suggesting that they will be able to inhibit $\mathrm{ChE}$ induced $\mathrm{A} \beta$ aggregation. Novel multi-target agents that exhibit good ChE inhibition (8d and 14) and anti-oxidant (8d) activity were identified as suitable candidates for further investigation.
\end{abstract}

Keywords: Alzheimer's disease, Cholinesterase, Molecular docking, Multi-target directed ligand, Tacrine, Trolox, Tryptoline.

\section{INTRODUCTION}

Alzheimer's disease (AD) is a chronic, multifactorial disease of the central nervous system [1]. Its characteristic symptoms include short-term memory impairment that worsens as the disease progresses and eventually leads to severe cognitive and physical disability [2]. AD represents the main cause of dementia and no curative drug is available. To date, it is estimated that 36.6 million people worldwide are suffering from the disease. This number is expected to double or triple by 2030 and 2050 [3]. The sequence of molecular events that underlies the occurrence of AD is still not well understood [4]. Current hypotheses suggest a decrease in the level of the neurotransmitter acetylcholine (ACh) in the brain regions involved in learning and memory, $\beta$-amyloid plaque formation $(\mathrm{A} \beta)$, oxidative stress, excitotoxicity, neuroinflammation and aggregation of tau proteins ( $\tau$-proteins) $[5,6]$. The current treatment of AD is limited to acetylcholinesterase inhibitor drugs (donepezil, galantamine and rivastigmine) and a $N$-methyl-D-aspartate receptor (NMDAR) antagonist (memantine, Fig. 1). These drugs act through the "one-molecule-one target" paradigm, offer only symptomatic treatment and do not stop the progression of $\mathrm{AD}$ [7].

A more appropriate strategy was proposed by developing multitarget directed ligands (MTDL) with the ability to modulate multiple targets involved in the pathogenesis of AD simultaneously [8,9]. Numerous examples (Fig. 2) of hybrid compounds with multifunctional activities have already been developed and published, including bis-7-tacrine dimers [10], galantamine-memantine hybrids [8], phenylthiazole-tacrine hybrids [9] and bivalent $\beta$-carboline hybrids [11] with pharmacological profiles offering promise of slowing or stopping neurodegenerative disease progression.

\footnotetext{
* Address correspondence to this author at the Pharmaceutical Chemistry, School of Pharmacy, University of the Western Cape, Private Bag X17, Bellville 7535, South Africa; Tel: +27 21959 3190; E-mail: sfmalan@uwc.ac.za
} 
These positive findings in the development of multifunctional hybrid compounds have prompted us to develop new hybrid compounds using tacrine, trolox and tryptoline as lead compounds (Fig. 3).

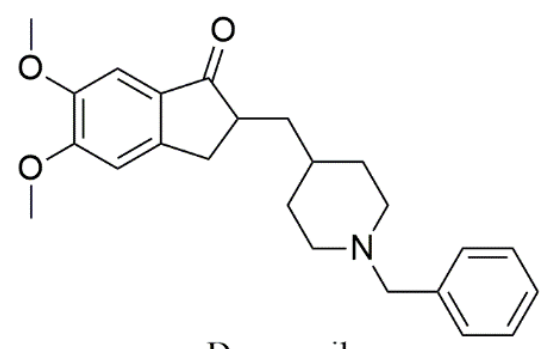

Donepezil<smiles>CCN(C)C(=O)Oc1cccc(C(C)N(C)C)c1</smiles>

Rivastigmine<smiles>COc1ccc2c3c1O[C@H]1C[C@@H](O)C=C[C@]31CCN(C)C2</smiles>

Galantamine

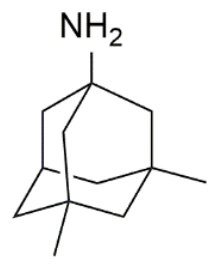

Memantine

Fig. (1). Chemical structures of current $\mathrm{AD}$ drugs.

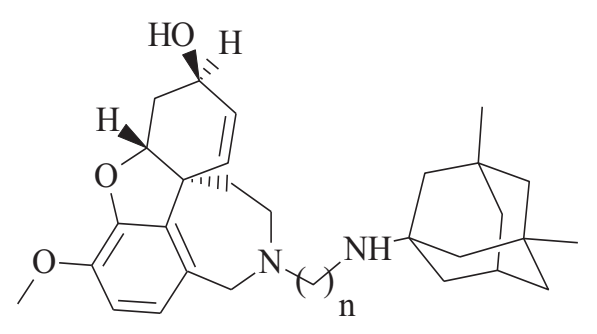

Galantamine-Memantine<smiles>c1ccc(-c2csc(NCCNc3c4c(nc5ccccc35)CCCC4)n2)cc1</smiles>

Phenylthiazole-tacrine hybrid

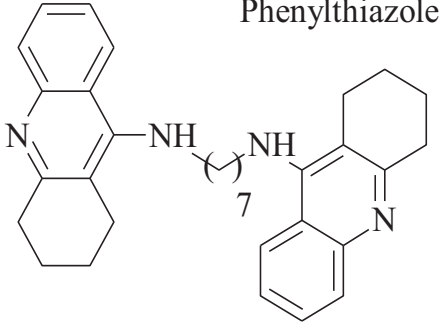

Bis-7-Tacrine dimer

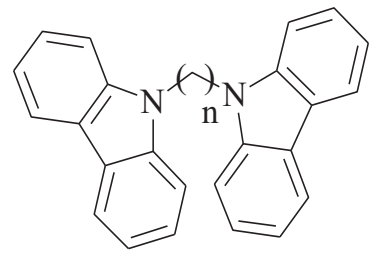

Bivalent $b$-carboline

Fig. (2). Chemical structures of multifunctional $\mathrm{AD}$ agents.

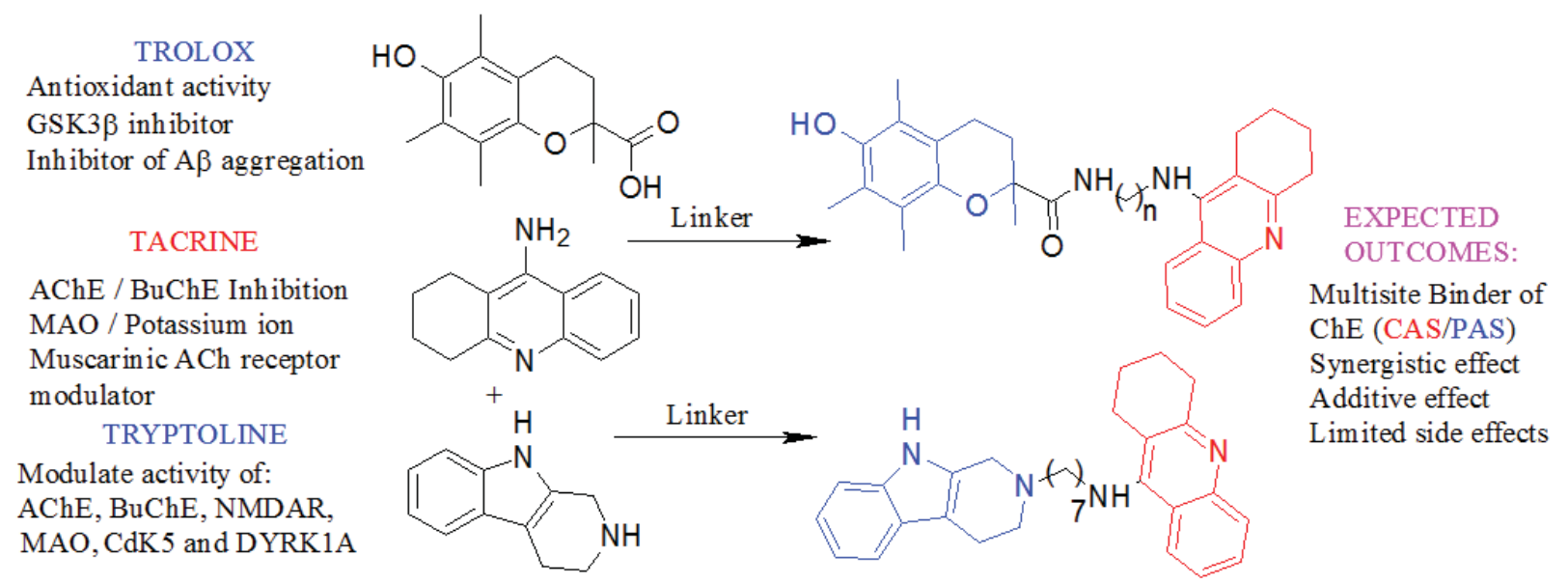

Fig. (3). Design strategy towards tacrine-trolox and tacrine-tryptoline hybrids.

Tacrine is an attractive lead compound that has successfully been used in the multitarget design strategy [9, 10]. It has ChE inhibitory activity and additional biological activity such as monoamine oxidase (MAO) inhibition and ion channel modulating ability [12] that may be of value in the treatment of AD has been described for it. Recent studies have demonstrated that lead optimization of tacrine in the design of novel AD drugs can improve its biological profile 
and alleviate its hepatotoxicity [13]. Based on these studies, tacrine appears to be a suitable lead compound for the design of multitarget agents. Trolox is an analog of Vitamin E ( $\alpha$-tocopherol) with well documented antioxidant capacity which may neutralize free radical species believed to be linked to aging or diseases such as AD [14]. Trolox also has the ability to prevent neurotoxicity induced by $\mathrm{A} \beta$ and hydrogen peroxide [15]. Another source revealed that trolox could inhibit glycogen synthase kinase $3 \beta$ (GSK $3 \beta$ ) whose hyperactivity causes neurofibrillary tangle formation [16]. These different biological activities of trolox consolidate its neuroprotective capacity and make it an excellent lead for the design of multifunctional drugs for treating AD. Tryptoline is a $\beta$-carboline derivative and derivatives thereof have been shown to inhibit ChE, MAO, NMDAR and other targets involved in the proposed pathogenesis of AD [17, $18]$.

Based on the topology of the active site of AChE we hypothesized that the combination of tacrine with trolox or tryptoline through linkers of varied chain lengths would lead to multifunctional hybrid compounds with the ability to modulate a number of important drug targets in the neurodegenerative cascade (Fig. 4). It is expected that the tacrine moiety will interact with conserved aromatic residues in the catalytic anionic site (CAS) of AChE necessary for AChE inhibition while trolox or tryptoline will interact with conserved aromatic residues in the peripheral anionic site (PAS) necessary for the possible prevention of AChE-induced A $\beta$ aggregation [19 - 22]. Varying the linker chain length explores the appropriate binding of the pharmacophores in the active site of AChE. The aim of these hybrids is to provide additive or synergistic therapeutic effects that might help overcome the limitation of current AD drugs and to aid in the search for novel AD lead compounds.

\section{RESULT AND DISCUSSION}

\subsection{Synthesis}

The synthesis of the tacrine-trolox hybrids $(\mathbf{8 a}-\mathbf{8 d})$ required intermediate 9-chloro-1,2,3,4-tetrahydroacridine (4), which was obtained from two sequential reactions; condensation of anthranilic acid (1) and cyclohexanone (2), followed by a reaction of the Spiro intermediate (3) with phosphoryl chloride. The intermediate (4) was then aminated in the microwave with appropriate alkyl diamine linkers followed by conjugation to trolox through an amide bond using the activation agent $N, N$-carbonyldiimidazole to give compounds 8a - 8d (Scheme 1). The tacrine-tryptoline hybrid (14) was synthesized by a two-step reaction including amination of 1,7-dibromoheptane with 9-amino-1,2,3,4tetrahydroacridine to produce intermediate 12, followed by conjugation to tryptoline through a further amination reaction. The tryptoline dimer (16) was obtained as a side-product from the reaction of tryptoline with an excess amount of 1,2-dibromoethane (Scheme 2) in a failed attempt to synthesize the tryptoline-bromoethane monomer. Compound 16 was added to the series of test compounds as a serendipitously synthesized compound that could show some biological activities because of possible fit inside the $\mathrm{ChE}$ active site cavity.

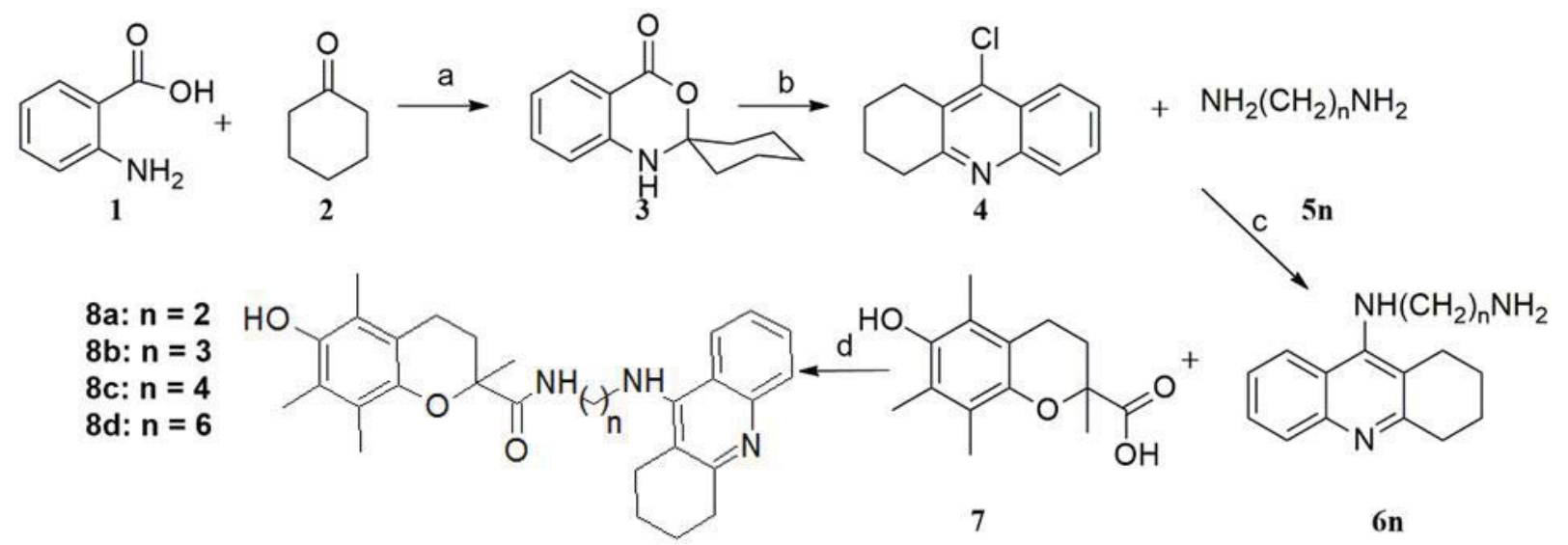

Scheme 1. Reagents and conditions: (a) anthranilic acid (1), cyclohexanone (2), toluene, reflux, 4 hrs; (b) spiro[2H-3,1benzoxazine-2,1-cyclohexane]-4(1H)-one (3), $\mathrm{POCl}_{3}$, alkaline workup (KOH), 2 hrs; (c) 9-chloro-1,2,3,4-tetrahydroacridine (4), alkylenediamines in excess (5n), DCM, $\mathrm{NaHCO}_{3}$, microwave irradiation at $200 \mathrm{C}, 250 \mathrm{~W}$ and maximum pressure for 30 minutes; (d) $N^{l}$-(1,2,3,4-tetrahydroacridin-9-yl)-alkane-1,n-diamine (6n), Trolox (7), $N, N$-carbonyldiimidazole, THF, rt, overnight, giving the tacrine-trolox hybrids $(\mathbf{8 a}-\mathbf{8 d})$. 


\subsection{Cholinesterase Inhibition Studies}

The selective loss of cholinergic neurons in $\mathrm{AD}$ results in a deficit of acetylcholine (ACh) in specific regions of the brain that mediate learning and memory functions [23]. Consequently, AD patients have been treated with AChE inhibitors [24 - 26] but unfortunately with limited therapeutic success, mainly because of the multifactorial nature of AD. Recent studies have also shown that compounds that are able to inhibit butyrylcholinesterase (BuChE) may be of value in the treatment of $\mathrm{AD}$ [27]. In $\mathrm{AD}$, the ratio of $\mathrm{BuChE/AChE}$ gradually increases as the disease progresses, partially as a consequence of the progressive loss of the cholinergic synapses where AChE enzymes are located [28]. A compound able to inhibit both AChE and BuChE may thus be of more therapeutic value in AD.<smiles>Nc1c2c(nc3ccccc13)CCCC2</smiles><smiles>Nc1c2c(nc3ccccc13)CCCC2</smiles><smiles>BrCCNc1c2c(nc3ccccc13)CCCC2</smiles>

12<smiles>CCN1N=C2CCCCC2=C(NCN2CCc3c([nH]c4ccccc34)C2)c2ccccc21</smiles><smiles>CCCC(=C(C)CC)c1ccccc1</smiles><smiles>BrCCCCBr</smiles>

15

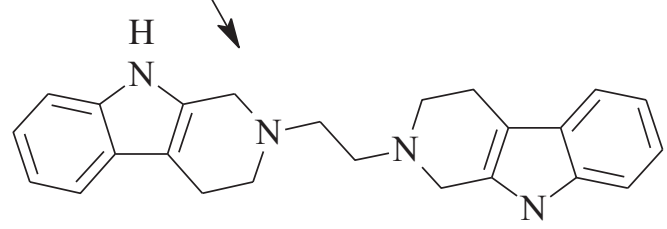

16

$\mathrm{H}$

Scheme 2. Reagents and conditions: (e) tacrine hydrochloride (9), $\mathrm{H}_{2} \mathrm{O}, \mathrm{K}_{2} \mathrm{CO}_{3}, 1 \mathrm{hr}$; (f) tacrine (10), 1,7-dibromoheptane (11), $\mathrm{CH}_{3} \mathrm{CN}, \mathrm{KOH}$, rt, overnight; (g) $N$-(7-bromoheptyl)-1,2,3,4-tetrahydroacridin-9-amine (12), tryptoline (13), $\mathrm{DMF}, \mathrm{K}_{2} \mathrm{CO}_{3}, \mathrm{KI}$, microwave $160 \mathrm{C}, 250 \mathrm{PSI}, 200 \mathrm{~W}, 1 \mathrm{~h}$, giving the tacrine-tryptoline hybrid (14); (h), tryptoline (13), 1,2-dibromoethane (15), KOH, $\mathrm{CH}_{3} \mathrm{CN}$, microwave $100 \mathrm{C}, 250 \mathrm{PSI}, 130 \mathrm{~W}, 1 \mathrm{hr}$, giving the bistryptoline dimer (16).

The inhibitory activity of the target compounds $\mathbf{8 a}-\mathbf{8 d}, \mathbf{1 4}$ and $\mathbf{1 6}$ against TcAChE (from electric eel) and eqBuChE (from equine serum) were measured according to the method of Ellman using tacrine and donepezil as reference compounds [29]. The $\mathrm{IC}_{50}$ values of the test compounds and reference compounds are given in Table 1. The tacrine-trolox hybrid compounds $(\mathbf{8 a}-\mathbf{8 d})$ showed moderate to high AChE inhibitory activities $\left(\mathrm{IC}_{50}: 49.31-2200 \mathrm{nM}\right)$ comparable to or better than the reference compounds donepezil, tacrine and previously reported $\beta$-carbolines [30]. Compound $\mathbf{1 6}$ displayed no inhibitory activity against AChE and though tryptoline is known to have AChE inhibitory activity, it is possible that the two carbon linker chain length limited the flexibility of the tryptoline moieties and prevented the dimer from adopting a stable conformation for effective activity. This scenario is slightly different for $\mathbf{8 a}$ where the 2 carbon linker chain length is extended by the amide bond conferring moderate AChE inhibitory activity. Compound $\mathbf{8 d}\left(\mathrm{IC}_{50}=49.31 \mathrm{nM}\right)$ with a 6 carbon linker displayed higher activities than $\mathbf{8 a}, \mathbf{8 b}$ and $\mathbf{8 c}$ with 2,3 and 4 carbon linker chain lengths respectively. Compound 14 with the 7 carbon linker exhibited the highest activity $\left(\mathrm{IC}_{50}=\right.$ $17.37 \mathrm{nM}$ ) and this correlates to the modelling study that clearly illustrate the interaction of the two pharmacophore moieties (tacrine and tryptoline) with Trp84 and Trp279, which are crucial for AChE activity (Fig. 5). In this series, it is clear that hybrids with longer linker chain lengths show increased AChE inhibitory activities compared to the shorter ones. This correlates well with other studies described in the literature [8-11]. The idea of varying linker chain length seeks to assign to the two linked pharmacophore units, the ability to span the PAS and CAS of AChE, and obtain the appropriate orientation that would enable them to interact with crucial amino acids in the active site, generating better activities. As confirmed by these results, shorter linker chain lengths (less than 4 carbons) are less favorable for optimal activity. 
Table 1. In vitro $\mathrm{IC}_{50}$ values of test compounds $8 \mathrm{a}-8 \mathrm{~d}, 14$ and 16 for TcAChE, eqBuChE and DPPH.

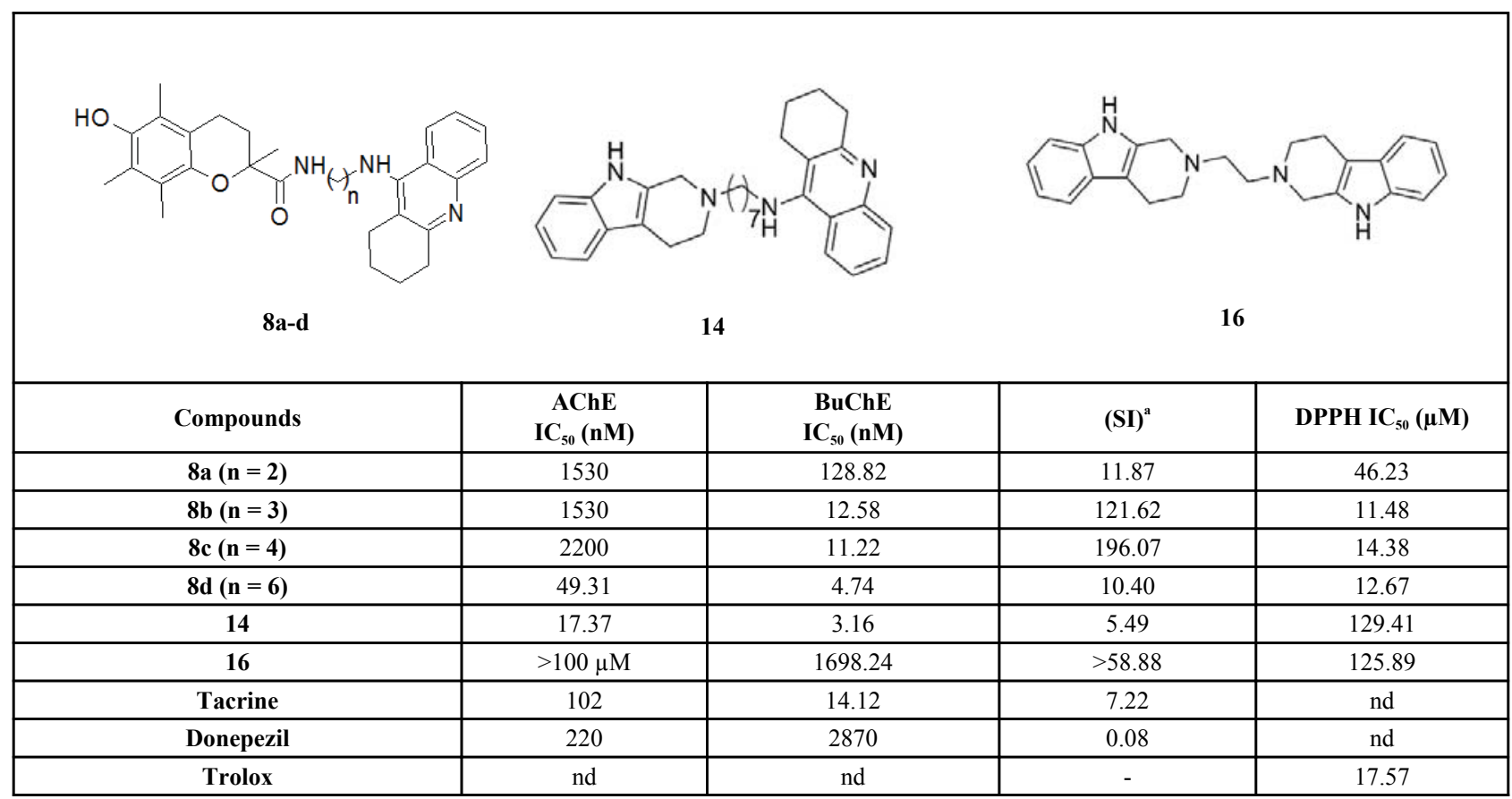

${ }^{a} \mathrm{BuChE}$ selectivity index $=\mathrm{IC}_{50}(T c \mathrm{AChE}) / \mathrm{IC}_{50}(\mathrm{eqBuChE})$. n.d. $=$ not determined.

The test compounds showed moderate to high BuChE inhibitory activities comparable or higher than their reference compound tacrine (Table 1) and previously reported $\beta$-carbolines [30]. Compound $\mathbf{8 d}\left(\mathrm{IC}_{50}=4.74 \mathrm{nM}\right)$ and $\mathbf{1 4}\left(\mathrm{IC}_{50}=\right.$ $3.16 \mathrm{nM}$ ) with 6 and 7 carbon linker chain lengths respectively displayed higher activities than $\mathbf{8 a}, \mathbf{8 b}$, and $\mathbf{8 c}$ with 2,3 and 4 carbons linker chain lengths. It can be deduced from this observation that hybrids with longer linker chain lengths also seem to exhibit increased BuChE inhibitory activities compared to the shorter ones. This similarity of interaction of synthesized compounds and target proteins ( $\mathrm{AChE} / \mathrm{BuChE}$ ) is consistent with the similarity of the topology of their active sites. Compounds 8d and $\mathbf{1 4}$ exhibited BuChE inhibitor activity more than 3 fold higher than tacrine. All the synthesized compounds showed higher inhibitory activity for BuChE than for AChE. It has been demonstrated that the two proteins share $65 \%$ amino acid sequence similarity and the $35 \%$ difference in their amino sequence confer to BuChE the ability to accommodate bulkier substrates than AChE [31]. The similarity in amino acid sequence of AChE and $\mathrm{BuChE}$ may prove to be a challenge in efforts to design a $100 \%$ non-selective cholinesterase inhibitor. The goal of this study was however to discover new dual inhibitors of cholinesterase since both proteins are believed to contribute, to different degrees, to the depletion of ACh levels in AD brain [24 - 28]. Based on this observation, selective inhibitors could be less effective as therapeutic options.

\subsection{Cholinesterase Molecular Modelling Studies}

To provide insight into the binding mode of the synthesized compounds docking studies were carried out on $T c \mathrm{AChE}$ and eqBuChE. The protein structure of TcAChE co-crystallized with tacrine (PDB code: $2 \mathrm{CMF}$ ) was retrieved from the Brookhaven Protein Data Bank (www.rcsb.org/pdb) and docking was carried out using the Dock application of Molecular Operating Environment (MOE 2015.10) software.

The BuChE molecular modeling experiments were conducted using a homology model because of the absence of a X-ray structure of eqBuChE. The automated homology-modeling program, SWISS-MODEL, was used to model the putative three-dimensional structure of eqBuChE based on the crystal structure of hBuChE (PDB: 2PM8) which shows an $89 \%$ sequence similarity [32]. The docking of the compounds into this homology model of eqBuChE was carried out with Autodock Vina software [33]. The docking results generated were directly loaded into and analyzed with MOE. 

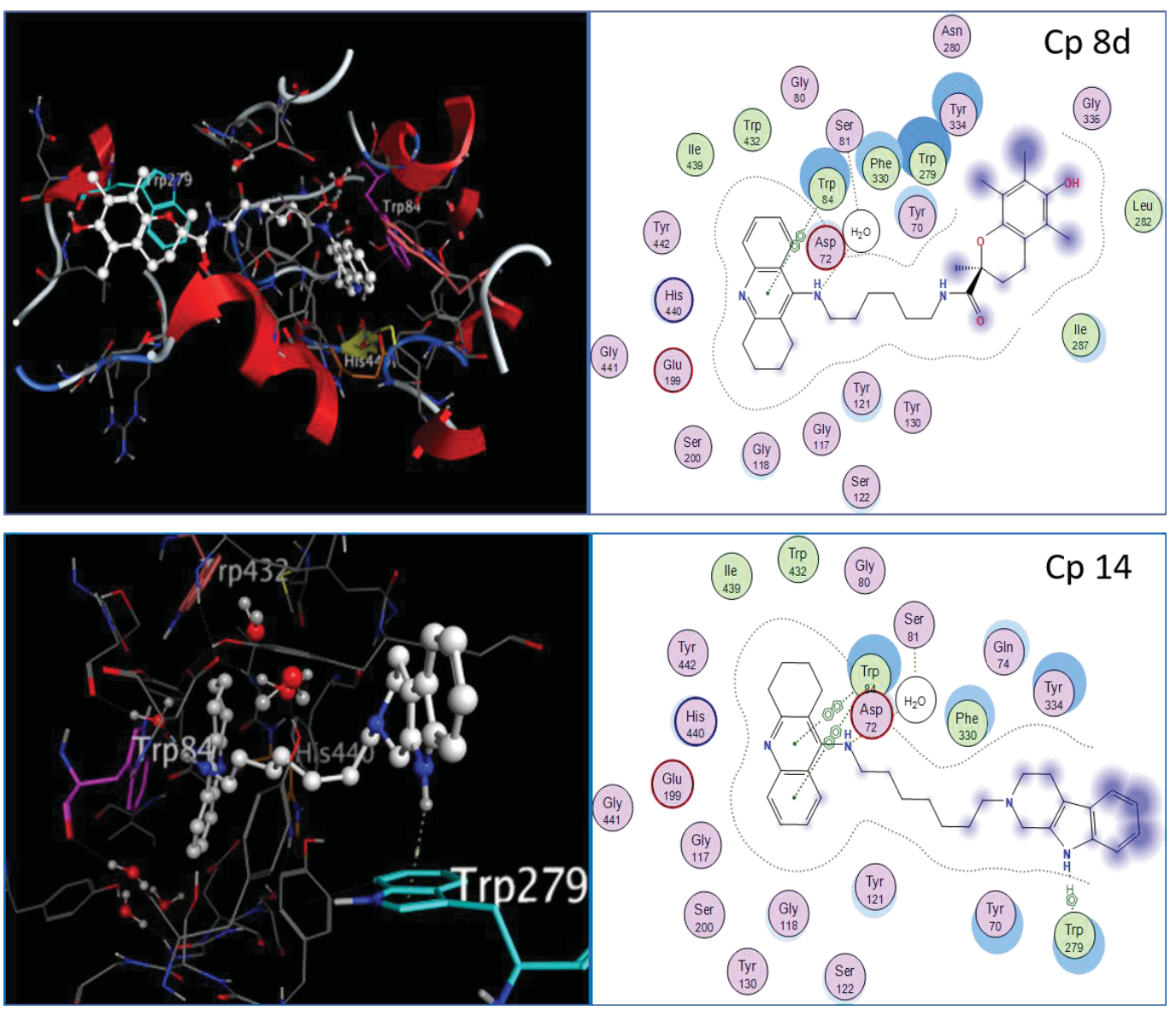

Fig. (4). Compounds 8d (top) and $\mathbf{1 4}$ (bottom) docked into the active site of $T c \mathrm{AChE}$ (left) and possible ligands interactions with conserved aromatic residues (right). Compounds $\mathbf{8 d}$ and $\mathbf{1 4}$ below are shown in white. In pink and cyan are Trp84 (CAS) and Trp 279 (PAS), crucial amino acids regularly involved in inhibition of AChE.

The docking revealed that the tacrine-trolox hybrids $\mathbf{8 a}-\mathbf{8 d}$, the tacrine-tryptoline hybrid (14) and the tryptoline dimer (16) show similar binding patterns. All the compounds spanned the CAS and PAS of TcAChE but with different energy scores. Compounds with the short linker chain lengths tend to have higher energy scores of $-8.10 \mathrm{kcal} / \mathrm{mol}$ (16) and $-9.84 \mathrm{kcal} / \mathrm{mol} \mathbf{( 8 a )}$ while $\mathbf{8 b}, \mathbf{8 c}, \mathbf{8 d}$ and $\mathbf{1 4}$ have relatively lower energy scores of $-10.20 \mathrm{kcal} / \mathrm{mol},-10.30$ $\mathrm{kcal} / \mathrm{mol},-11.43 \mathrm{kcal} / \mathrm{mol}$ and $-10.40 \mathrm{kcal} / \mathrm{mol}$, respectively. The difference in energy scores indicate a disparity in how strong / fast / stable the synthesized compounds bind to the active site. Based on this concept, compounds with longer linker chain lengths should display the highest activity. This is in line with the biological results where the same trend was observed. In all docking experiments, tacrine occupied the CAS and trolox / tryptoline occupied the PAS, which correlated well with our hypothesis and also demonstrated the high selectivity of the tacrine moiety for the CAS as supported in the literature [31]. Fig. (4) shows the docking and binding interactions of compounds 8d and $\mathbf{1 4}$ in $T c \mathrm{AChE}$. It is clear from the images that the quinoline ring of tacrine form $\pi-\pi$ interactions with Trp84 in both compounds 8d and $\mathbf{1 4}$ with the trolox and tryptoline moieties reaching the PAS region of the enzyme. An H- $\pi$ interaction is also observed with compound (14) between 9-H of the tryptoline moiety and Trp279 in the PAS. These results confirm that the hybrid compounds are able to span both the CAS and PAS of AChE which may account for the promising AChE inhibitory activity observed. The molecular modeling experiments were also done with the test compounds in their protonated state. The only additional interaction observed was an ionic interaction between the protonated acridine nitrogen and HIS440. The binding energies and orientation of the molecules did not show any significant differences when compared to their protonated counterparts.

To explore the binding mode in eqBuChE, compounds $8 \mathbf{d}$ and $\mathbf{1 4}$ were used as representative compounds and were docked into the active site of the eqBuChE homology build model (Fig. 5). The docking results of $\mathbf{8 d}$ and $\mathbf{1 4}$ showed that the tacrine moiety binds in the CAS region, establishing $\pi-\pi$ stacking interactions with Trp82. In both these compounds the trolox and tryptoline moieties spanned the active site gorge and were stabilized within the PAS region 
of eqBuChE. The binding energies of $\mathbf{8 d}$ and 14 were $-11.83 \mathrm{kcal} / \mathrm{mol}$ and $-12.23 \mathrm{kcal} / \mathrm{mol}$, respectively. The low binding energies and favourable positions of $\mathbf{8 d}$ and $\mathbf{1 4}$ within the active site of eqBuChE may account for the high affinity and slight selectivity observed for BuChE over AChE. As observed for the AChE docking experiments, when the molecules were redocked in their protonated state, no significant difference was observed in their binding orientations or binding energies. An additional ionic interaction between the protonated acridine amine and HIS438 was the only additional binding interaction predicted.
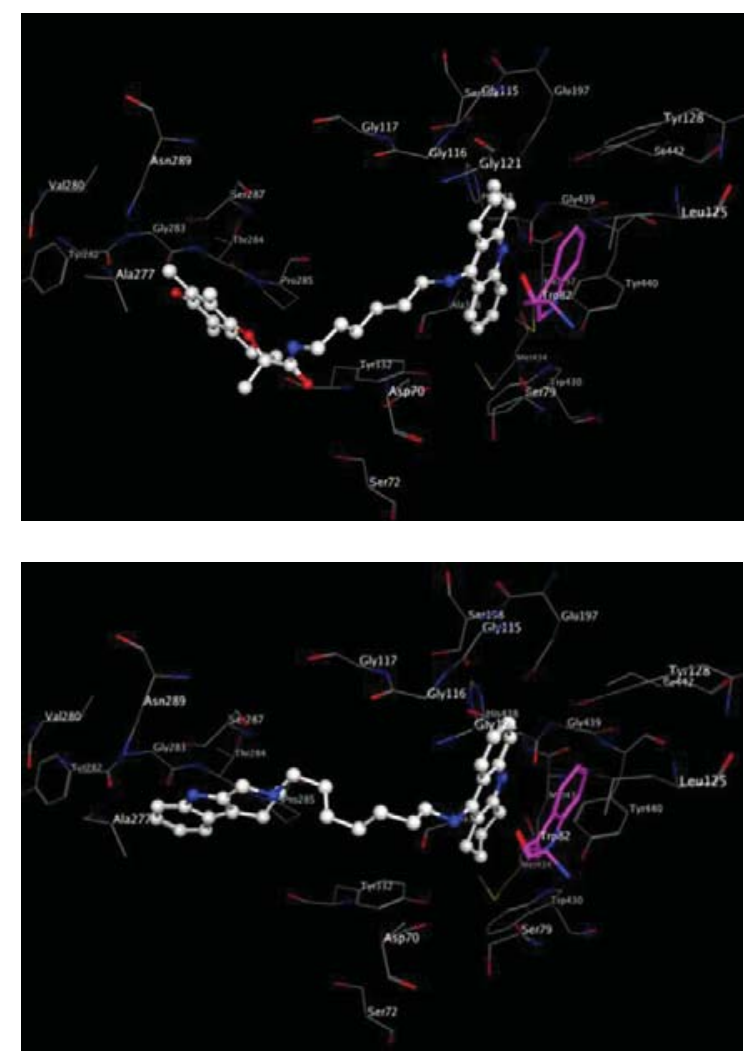
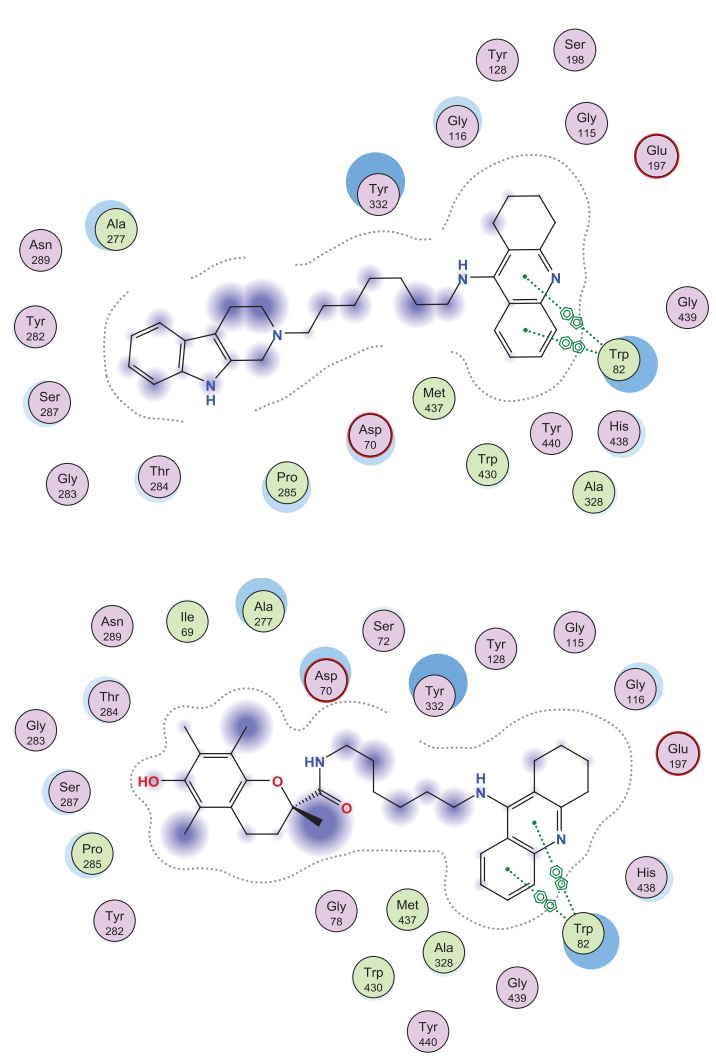

Fig. (5). Complex of compound $\mathbf{8 d}$ (top) and $\mathbf{1 4}$ (bottom) with the eqBuChE homology model (left) and the interaction maps (right). Compounds $\mathbf{8 d}$ and $\mathbf{1 4}$ below are shown in white and Trp82 in the CAS site is shown in pink.

\subsection{Anti-oxidant Studies}

Reactive oxygen and nitrogen species contribute to the pathophysiology of neurodegenerative disorders [34]. Antioxidants are compounds capable of scavenging free radicals and antioxidant therapy is therefore considered as one of the options in neuroprotection [14]. The 2,2-diphenyl-1-picrylhydrazyl (DPPH) assay was used to assess the free radical scavenging or antioxidant effect of the test compounds. The synthetic nitrogen-centred $\mathrm{DPPH}^{{ }^{+}}$is not biologically relevant, but is used as indicator compound in testing hydrogen transfer capacity related to antioxidant activity [35]. The results of the ability of synthesized compounds to scavenge the DPPH free radical are included in Table 1. Trolox has well documented antioxidant properties and was used as reference compound in this assay. The conjugation of trolox to tacrine through varying linker chain lengths did not affect its ability to scavenge free radicals. The tacrine-trolox compounds $\left(\mathbf{8 b}-\mathbf{8 d}, \mathrm{IC}_{50}: 11.48-14.38 \mu \mathrm{M}\right)$ exhibited activity with $\mathrm{IC}_{50}$ values in the same range as that of trolox $\left(\mathrm{IC}_{50}=17.57 \mu \mathrm{M}\right)$. The exception is compound $\mathbf{8 a}\left(\mathrm{IC}_{50}: 46.23 \mu \mathrm{M}\right)$ which showed free radical scavenging activity of about half of that of trolox. Compounds $\mathbf{1 4}$ and $\mathbf{1 6}$ exhibited lower free radical scavenging activity with $\mathrm{IC}_{50}$ values of $129.41 \mu \mathrm{M}$ and $125.24 \mu \mathrm{M}$. This was expected as the trolox moiety is replaced by the less potent free radical scavenging tryptoline moiety.

\section{EXPERIMENTAL SECTION}

Unless otherwise specified, materials were obtained from commercial suppliers and used without further purification. All reactions were monitored by thin-layer chromatography on $0.20 \mathrm{~mm}$ thick aluminium silica gel sheets (Alugram ${ }^{\circledR}$ SIL G/UV254, Kieselgel 60, Macherey-Nagel, Düren, Germany). Visualization was achieved using UV light 
(254 nm and $366 \mathrm{~nm}$ ), an ethanol solution of ninhydrin or iodine vapours, with mobile phases prepared on a volume-tovolume basis. Chromatographic purifications were performed on silica gel (0.063-0.2 mm, Sigma Aldrich) except when otherwise stated. The MS spectra were recorded on a Perkin Elmer Flexar SQ 300 mass spectrometer by means of direct injection with a syringe pump. High resolution electron spray ionisation (HREI) mass spectra for all compounds were recorded on a Waters API Q-Tof Ultima mass spectrometer at $70 \mathrm{eV}$ and $100{ }^{\circ} \mathrm{C}$. The IR spectra were recorded on a Perkin Elmer Spectrum 400 spectrometer, fitted with a diamond attenuated total reflectance (ATR) attachment. Melting points were determined using a Stuart SMP-300 melting point apparatus and capillary tubes. All the melting points determined were recorded uncorrected. ${ }^{1} \mathrm{H}$ and ${ }^{13} \mathrm{C}$ NMR spectra were determined using a Bruker Avance III HD spectrometer at a frequency of $400 \mathrm{MHz}$ and $100 \mathrm{MHz}$, respectively. Tetramethylsilane (TMS) was used as internal standard. All chemical shifts are reported in parts per million (ppm), relative to the internal standard. The following abbreviations are used to indicate the multiplicities of the respective signals: s - singlet; br s - broad singlet; $d$ - doublet; $\mathrm{dd}$ - doublet of doublets; $\mathrm{t}$ - triplet and $\mathrm{m}$ - multiplet.

\subsection{Chemistry}

\subsubsection{Synthesis of spiro[2H-3,1-benzoxazine-2,1-cyclohexan]-4(1H)-one (3)}

In $100 \mathrm{ml}$ toluene in a $250 \mathrm{ml}$ round bottom flask was dissolved $50 \mathrm{~g}(0.40 \mathrm{~mol})$ anthranilic acid (1) and $45.3 \mathrm{ml}$ (0.44 mol) cyclohexanone (2) was added. The mixture was refluxed for $4 \mathrm{hrs}$ using a Dean-Stark trap until approximately $6.8 \mathrm{ml}$ water was collected. The reaction mixture was cooled to room temperature and needle likecrystals were formed. The solid was collected by filtration and successively washed with $50 \mathrm{ml}$ toluene and $50 \mathrm{ml}$ ethanol. The solid was then dried in vacuo and $72.51 \mathrm{~g}$ white crystals were collected which afforded a yield of $90.91 \%$ of product (3) with physical characteristics similar to that described in the literature [37].

\subsubsection{Synthesis of 9-chloro-1,2,3,4-tetrahydroacridine (4)}

In a $250 \mathrm{ml}$ round bottom flask, containing $120 \mathrm{ml}(1.29 \mathrm{~mol})$ of $\mathrm{POCl}_{3}$ was added $67 \mathrm{~g}(0.309 \mathrm{~mol})$ of 3 and the mixture was refluxed on an oil bath at $120 \mathrm{C}$ for $2 \mathrm{hrs}$. The reaction mixture was then cooled to room temperature and cautiously added to $540 \mathrm{~g} \mathrm{KOH}$ in $1000 \mathrm{ml}$ ice water while being stirred rapidly. $\mathrm{CH}_{2} \mathrm{Cl}_{2}$ (1500 ml) was added to dissolve the solid. The aqueous layer was extracted with $3 \times 1000 \mathrm{ml} \mathrm{CH}_{2} \mathrm{Cl}_{2}$. The combined organic extracts were dried with $\mathrm{MgSO}_{4}$. The mixture was filtered and the solvent was removed on a rotary evaporator to give a yellow solid, which was further recrystallized in acetone to give $64 \mathrm{~g}$ of pure yellow clear crystals (4) with similar physical characteristics as described in the literature [37].

\subsubsection{General Synthesis of $N^{l}(1,2,3,4-t e t r a h y d r o a c r i d i n-9-y l)$ alkane-1,n-diamines $(n=2,3,4$ or 6$)$}

To $0.43 \mathrm{~g}(1.98 \mathrm{mmol})$ of 4 contained in a microwave tube, was added $40.1 \mathrm{mmol}$ of the appropriate alkylenediamine (5n). The mixture was reacted for 30 minutes at $200 \mathrm{C}$ with $250 \mathrm{~W}$ power and maximum pressure. After cooling, $\mathrm{CH}_{2} \mathrm{Cl}_{2}(30 \mathrm{ml})$ was added to the reaction mixture. Excess alkylenediamine was extracted from the mixture with $3 \times 30 \mathrm{ml}$ of distilled water acidified to $\mathrm{pH} 5-6$ with diluted $\mathrm{HCl}$. The organic layers were collected, dried with $\mathrm{Na}_{2} \mathrm{SO}_{4}$ and filtered. The organic solvent was evaporated on a rotary evaporator to yield the final products (6n). The physical characteristics of these compounds were similar to as described in the literature [38].

\subsubsection{General Synthesis for the Tacrine-trolox Hybrids $(8 a-8 d)$}

To a solution of THF $(20 \mathrm{ml})$ containing $0.75 \mathrm{~g}(3 \mathrm{mmol})$ of trolox (7) was added $0.54 \mathrm{~g}(3.3 \mathrm{mmol})$ of $\mathrm{N}, \mathrm{N}$ carbanoyldiimidazole. The mixture was stirred at room temperature for 30 minutes before adding $3 \mathrm{mmol}$ of the appropriate $N^{l}$-(1,2,3,4-tetrahydroacridin-9-yl)alkane-1,n-diamine (6n) in $10 \mathrm{ml}$ THF. The resulting solution was reacted overnight at room temperature. Thereafter, the solvent was removed in vacuo and the residue was added to DCM $(25 \mathrm{ml})$ and extracted with acidified water $(\mathrm{pH} 3,3 \times 25 \mathrm{ml})$. The organic phase was further extracted with $5 \mathrm{~N}$ $\mathrm{NaOH}(\mathrm{aq})(3 \times 25 \mathrm{ml})$. The combined organic phases were dried over $\mathrm{MgSO}_{4}$ and the solvent was removed in vacuo rendering the crude products, which were first purified by flash column chromatography with acetone as mobile phase and then flushed with ethanol $(250 \mathrm{ml})$ to render the impure products $(\mathbf{8 n})$. A final purification was carried out by column chromatography for each compound with ethyl acetate:ethanol (1:1) as mobile phase to yield the pure products $(\mathbf{8 a}-\mathbf{8 d})$. 
3.1.4.1. 6-Hydroxy-2,5,7,8-tetramethyl-N-\{2-[(1,2,3,4-tetrahydroacridin-9-yl)amino]ethyl\}-3,4-dihydro-2H-1benzopyran-2-carboxamide (8a)

$\mathbf{C}_{29} \mathbf{H}_{35} \mathbf{N}_{3} \mathbf{O}_{3}$; yield 16\%; Physical data: MP: 33-35 C; $\mathbf{R f}$ (ethyl acetate:ethanol / 1:1) 0.3; ${ }^{1} \mathbf{H}$ NMR (400 MHz, $\left.\mathrm{CDCl}_{3}\right) \delta \mathrm{H}: 7.95(\mathrm{~d}, \mathrm{~J}=8.97 \mathrm{~Hz}, 1 \mathrm{H}), 7.87(\mathrm{~d}, \mathrm{~J}=8.97 \mathrm{~Hz}, 1 \mathrm{H}), 7.55-7.53(\mathrm{~m}, 1 \mathrm{H}), 7.32-7.26(\mathrm{~m}, 2 \mathrm{H}), 6.86(\mathrm{~s}, 1 \mathrm{H})$, 3.61-3.56 (m, 4H), 3.08-3.05 (m, 2H), 2.67-2.63 (m, 2H), 2.35-2.31 (m, 1H), 2.12-2.03 (m, 9H), $1.89(\mathrm{bs}, 6 \mathrm{H}), 1.52(\mathrm{~s}$, 3H); ${ }^{13}$ C-NMR $\left(100 \mathrm{MHz}, \mathrm{CDCl}_{3}\right), \delta \mathrm{C}: 176.6,148.9,145.9,143.9,141.5,133.3,129.9,129.7,129.0,128.7,124.4$, $122.9,121.8,117.7,78.3,50.3,40.2,31.9,29.7,29.4,25.3,24.7,24.4,22.6,21.9,20.4,14.1,12.3,11.3$. HR-ESI $[\mathrm{M}+\mathrm{H}]^{+}$: calcd. 474.2751, found. 474.2770; IR (ATR, $\left.\mathrm{cm}^{-1}\right) \mathrm{V}_{\max }: 3326,2924,1447,1091,760$.

3.1.4.2. 6-Hydroxy-2,5,7,8-tetramethyl-N-\{3-L(1,2,3,4-tetrahydroacridin-9-yl)aminolpropyl\}-3,4-dihydro-2H-1benzopyran-2-carboxamide $(8 \mathrm{~b})$

$\mathbf{C}_{30} \mathbf{H}_{37} \mathbf{N}_{3} \mathbf{O}_{3}$; Yield 25\%; Physical data: MP: 118-122 C; $\mathbf{R f}$ (ethyl acetate:ethanol / 1:1) 0.33; ${ }^{1} \mathbf{H}$ NMR (400 MHz, $\left.\mathrm{CDCl}_{3}\right) \delta \mathrm{H}:$ 7.93-7.87 (m, 2H), 7.51-7.49 (m, 1H), 7.34-7.31 (m, 2H), 6.71 (s, 1H), 3.47-3.35 (m, 4H), 3.08-3.04 (m, 2H), 2.68-2.60 (m, 5H), 2.07-2.03 (m, 9H), $1.87(\mathrm{bs}, 6 \mathrm{H}), 1.54(\mathrm{~s}, 3 \mathrm{H}) ;{ }^{13} \mathbf{C}-\mathbf{N M R}\left(100 \mathrm{MHz}, \mathrm{CDCl}_{3}\right), \delta \mathrm{C}: 175.6,157.8$, 151.6, 146.0, 144.3, 129.1, 127.5, 124.3, 122.7, 122.1, 121.8, 120.0, 119.6, 118.0, 116.3, 78.6, 45.4, 36.6, 32.9, 31.4, 29.9, 25.1, 24.9, 23.1, 22.6, 20.8, 12.4, 12.2, 12.0, 11.6. HR-ESI [M+H] $]^{+}$: calcd. 488.2908, found. 488.2914; IR (ATR, $\left.\mathrm{cm}^{-1}\right) \mathrm{V}_{\max }: 3326,2927,1447,760$.

3.1.4.3. 6-Hydroxy-2,5,7,8-tetramethyl-N-\{4-[(1,2,3,4-tetrahydroacridin-9-yl)amino/butyl\}-3,4-dihydro-2H-1benzopyran-2-carboxamide (8c)

$\mathbf{C}_{31} \mathbf{H}_{39} \mathbf{N}_{3} \mathbf{O}_{3}$; yield 13\%; Physical data: MP: 154-159 C; Rf (ethyl acetate:ethanol / 1:1) 0.36; ${ }^{1} \mathbf{H}$ NMR (400 MHz, $\left.\mathrm{CD}_{3} \mathrm{OD}\right), \delta \mathrm{H}: 8.15(\mathrm{~d}, \mathrm{~J}=8.45 \mathrm{~Hz}, 1 \mathrm{H}), 7.71-7.67(\mathrm{~m}, 2 \mathrm{H}), 7.46-7.42(\mathrm{~m}, 2 \mathrm{H}), 6.70(\mathrm{~s}, 1 \mathrm{H}), 3.59-3.46(\mathrm{~m}, 4 \mathrm{H})$, 3.32-3.28 (m, 2H), 3.06-2.62 (m, 5H), 2.08-2.05-1.93 (m, 9H), 1.90-1.86 (m, 4H), 1.45-1.44 (m, 4H), $1.40(\mathrm{~s}, 3 \mathrm{H})$; ${ }^{13} \mathbf{C}-$ NMR $\left(100 \mathrm{MHz}, \mathrm{CD}_{3} \mathrm{OD}\right), \delta \mathrm{C}: 174.7,153.9,153.6,145.9,144.2,142.0,130.6,124.6,123.7,123.6,122.6,121.6$, $120.2,117.8,117.5,113.0,78.3,48.1,38.4,30.5,29.7,28.0,26.9,24.5,24.4,21.5,20.6,12.6,12.2,12.0,11.7$. HRESI $[\mathrm{M}+\mathrm{H}]^{+}$: calcd. 502.3064, found. 502.3068; IR (ATR, $\mathrm{cm}^{-1}$ ) $\mathrm{V}_{\max }: 3370,2928,1520,1088,750,530$.

3.1.4.4. 6-Hydroxy-2,5,7,8-tetramethyl-N-\{6-/(1,2,3,4-tetrahydroacridin-9-yl)amino/hexyl\}-3,4-dihydro-2H-1benzopyran-2-carboxamide $(8 d)$

$\mathbf{C}_{33} \mathbf{H}_{43} \mathbf{N}_{3} \mathbf{O}_{3}$; yield 12\%; Physical data: MP: 146-149 C; Rf 0.46 (ethyl acetate-ethanol / 1:1); ${ }^{1} \mathbf{H}$ NMR (400 MHz, CDCl3), $\delta \mathrm{H}: 8.29(\mathrm{~d}, \mathrm{~J}=8.55 \mathrm{~Hz}, 1 \mathrm{H}), 8.19(\mathrm{~d}, \mathrm{~J}=8.55 \mathrm{~Hz}, 1 \mathrm{H}), 7.61-7.57(\mathrm{~m}, 2 \mathrm{H}), 7.40-7.336(\mathrm{~m}, 1 \mathrm{H}), 6.40(\mathrm{~s}, 1 \mathrm{H})$, 3.77-3.40 (m, 5H), $2.68(\mathrm{~m}, 2 \mathrm{H}), 2.52-2.43(\mathrm{~m}, 4 \mathrm{H}), 2.17-2.08(\mathrm{~m}, 9 \mathrm{H}), 1.85-1.77(\mathrm{~m}, 6 \mathrm{H}), 1.51(\mathrm{~s}, 3 \mathrm{H}), 1.23-1.19(\mathrm{~m}$, $6 \mathrm{H}) ;{ }^{13} \mathrm{C}-\mathbf{N M R}\left(100 \mathrm{MHz}, \mathrm{CDCl}_{3}\right), \delta \mathrm{C}: 174.5,155.4,151.4,146.2,144.4,139.3,131.9,124.9,124.5,122.9,121.4$, $120.9,118.1,116.1,11.4,78.5,48.2,38.7,38.5,30.9,29.7,29.4,28.8,26.9,26.3,25.8,25.4,24.1,22.1,20.9,13.1$, 12.9, 11.9; HR-ESI [M+H] $]^{+}$: calcd. 530.3377, found. 530.3387; IR (ATR, $\left.\mathrm{cm}^{-1}\right) \mathrm{V}_{\max }:$ 3270, 2932, $1520,1088,576$.

\subsubsection{Synthesis of N-(7-bromoheptyl)-1,2,3,4-tetrahydroacridin-9-amine (12)}

9-Amino-1,2,3,4-tetrahydroacridine $(780 \mathrm{mg})(\mathbf{1 0})$ was obtained by precipitating 9-amino-1,2,3,4-tetrahydroacridine hydrochloride $1 \mathrm{~g}(9)$ in a sodium hydrogen carbonate solution. To a solution of $\mathrm{CH}_{3} \mathrm{CN}(10 \mathrm{ml}) \mathrm{containing} 400 \mathrm{mg}$ $(2.01 \mathrm{mmol})$ of 10 in a $100 \mathrm{ml}$ round bottom flask was added $2.60 \mathrm{~g}$ (10.05 mmol) of 1,7-dibromoheptane (11) and 224 $\mathrm{mg}(4.02 \mathrm{mmol})$ of $\mathrm{KOH}$. The mixture was stirred at room temperature overnight. The reaction was monitored by TLC (mobile phase: ethyl acetate:hexane:TEA (10:10:1)). After completion, the reaction mixture was poured into $10 \mathrm{ml}$ of distilled water and extracted with DCM $(3 \times 20 \mathrm{ml})$. The combined organic layers were dried over anhydrous $\mathrm{Na}_{2} \mathrm{SO}_{4}$, filtered, and the solvent was evaporated under reduced pressure. The residue was purified by silica gel column chromatography using ethyl acetate:hexane:TEA (10:10:1) as eluent to produce $100 \mathrm{mg}(13.20 \%)$ of a pure yellow oil (12) with similar characteristics as described in the literature [39].

\subsubsection{Synthesis of N-(7-(3,4-dihydro-1H-pyrido[3,4-b]indol-2(9H)-yl)heptyl)-1,2,3,4-tetrahydroacridin-9-amine (14)}

In a microwave tube containing $5 \mathrm{ml}$ of DMF was dissolved $(70 \mathrm{mg}, 0.20 \mathrm{mmol})$ of $\mathbf{1 2}$. Tryptoline $(\mathbf{1 3}, 26.28 \mathrm{mg}$, $0.15 \mathrm{mmol})$ and of $\mathrm{K}_{2} \mathrm{CO}_{3}(38.80 \mathrm{mg}, 0.28 \mathrm{mmol})$ were added with a catalytic amount of KI. The mixture was irradiated in a microwave reactor at $160 \mathrm{C}, 250 \mathrm{PSI}$ and $200 \mathrm{~W}$ for $1 \mathrm{hr}$. The reaction was monitored by TLC (mobile phase: ethyl 
acetate-hexane-TEA in a ratio 10:10:1). After completion, the reaction mixture was poured into $5 \mathrm{ml}$ of distilled water and extracted with ethyl acetate $(3 \times 10 \mathrm{ml})$. The combined organic phase was washed with water, and then with a saturated $\mathrm{NaCl}$ solution $(3 \times 10 \mathrm{ml})$. The organic fraction was dried with anhydrous $\mathrm{Na}_{2} \mathrm{SO}_{4}$ and evaporated under reduced pressure. The residue was purified by silica gel column chromatography using ethyl acetate-hexane-TEA (10:10:1) to produce $18 \mathrm{mg}(25 \%)$ of a pure dark yellow solid (14).

$\mathbf{C}_{31} \mathbf{H}_{38} \mathbf{N}_{4}$; yield 25\%; MP: 98-101 C; Physical data: Rf (ethyl acetate-hexane-TEA / 10:10:1) 0.43; ${ }^{1} \mathbf{H}$ NMR (400 $\left.\mathrm{MHz}, \mathrm{CDCl}_{3}\right), \delta \mathrm{H}: 8.37(\mathrm{~s}, 1 \mathrm{H}), 7.98(\mathrm{~m}, 2 \mathrm{H}), 7.59-7.55(\mathrm{~m}, 1 \mathrm{H}), 7.45(\mathrm{~d}, \mathrm{~J}=7.29 \mathrm{~Hz}, 1 \mathrm{H}), 7.37-7.30(\mathrm{~m}, 2 \mathrm{H})$, 7.13-7.044 (m, 2H), 3.58-3.54 (m, 4H), $3.08(\mathrm{~s}, 2 \mathrm{H}), 2.83-2.80(\mathrm{~m}, 4 \mathrm{H}), 2.68(\mathrm{t}, \mathrm{J}=6.02 \mathrm{~Hz}, 2 \mathrm{H}), 2.54(\mathrm{t}, \mathrm{J}=7.67 \mathrm{~Hz}$, 2H), $1.90(\mathrm{~m}, 4 \mathrm{H}), 1.67-1.65(\mathrm{~m}, 2 \mathrm{H}), 1.53(\mathrm{~m}, 2 \mathrm{H}), 1.35(\mathrm{~m}, 6 \mathrm{H}) ;{ }^{13} \mathbf{C}-\mathbf{N M R}\left(100 \mathrm{MHz}, \mathrm{CDCl}_{3}\right), \delta \mathrm{C} 157.7,151.6$, 136.2, 132.0, 129.0, 127.8, 123.9, 123.1, 121.3, 119.7, 117.9, 115.2, 110.9, 108.3, 57.9, 51.4., 50.4, 49.4, 33.3, 31.7, 29.2, 27.4, 27.3, 26.8, 24.8, 23.0, 22.6, 21.4, 18.6; HR-ESI [M+H] $]^{+}$: calcd. 467.3169, found. 467.3166; IR (ATR, $\left.\mathrm{cm}^{-1}\right)$ $\mathrm{V}_{\max }: 3214,2926,1563,740$.

\subsubsection{Synthesis of 1,2-Bis(3,4-dihydro-1H-pyrido[3,4-b]indol-2(9H)-yl)ethane (16)}

To a solution of $\mathrm{CH}_{3} \mathrm{CN}(20 \mathrm{ml})$ containing $0.4 \mathrm{~g}(2.32 \mathrm{mmol})$ of $\mathbf{1 3}$ in a $100 \mathrm{ml}$ round bottom flask was added 2.20 $\mathrm{g}(11.61 \mathrm{mmol})$ of 1,2-dibromoethane $(\mathbf{1 5})$ and $\mathrm{KOH}(0.30 \mathrm{mg}, 4.63 \mathrm{mmol})$. The mixture was irradiated in microwave reaction at $130 \mathrm{~W}, 250 \mathrm{PSI}$ and $100 \mathrm{C}$ for $1 \mathrm{hr}$ ). The reaction was monitored with TLC (mobile phase: methanol). After completion of the reaction, the solvent was evaporated under reduced pressure and the resulting solid residue was dissolved in methanol and purified by silica gel column chromatography (mobile phase: methanol) to yield an impure powder-like product, which was further subjected to 2 cycles of recrystallization in ethanol to afford $150 \mathrm{mg}$ of a pure pale-white solid (16).

$\mathbf{C}_{24} \mathbf{H}_{26} \mathbf{N}_{4}$; yield 17\%; Physical data: MP: 255-260 C; Rf (methanol) 0.57; ${ }^{1} \mathbf{H} \mathbf{N M R}\left(400 \mathrm{MHz},\left(\mathrm{CD}_{3}\right)_{2} \mathrm{SO}\right): \delta \mathrm{H}$ : $10.70(\mathrm{~s}, 2 \mathrm{H}), 7.35(\mathrm{~m}, 4 \mathrm{H}), 6.97(\mathrm{~m}, 4 \mathrm{H}), 3.69(\mathrm{~s}, 4 \mathrm{H}), 3.35(\mathrm{~s}, 4 \mathrm{H}), 2.80(\mathrm{bs}, 4 \mathrm{H}), 2.68(\mathrm{~s}, 4 \mathrm{H}) ;{ }^{13} \mathbf{C}-\mathbf{N M R}(100 \mathrm{MHz}$ $\left.\left(\mathrm{CD}_{3}\right)_{2} \mathrm{SO}\right), \delta \mathrm{C}: 135.8,132.9,126.7,120.2,118.2,117.3,110.9,106.4,55.3,51.2,50.5,21.3 ;$ HR-ESI [M+H] ${ }^{+}$: calcd. 371.2230, found. 371.2233; IR (ATR, $\mathrm{cm}^{-1}$ ) $\mathrm{V}_{\max }: 3374,2815,1450,741$.

\subsection{Cholinesterase Assay}

AChE from electric eel, BuChE from equine serum, S-butylthiocholine iodide (BTCI), acetylthiocholine iodide (ATCI), 5,5'-dithiobis-(2-nitrobenzoic acid) (Ellman's reagent, DTNB), donepezil and tacrine hydrochloride were purchased from Sigma-Aldrich. The inhibitory activities of the test compounds were evaluated by Ellman's method [29]. The compounds were dissolved in DMSO and diluted with the buffer solution (50 $\mathrm{mM}$ Tris $-\mathrm{HCl}, \mathrm{pH}=8.0)$ to yield the corresponding test concentrations (DMSO less than $0.01 \%$ ). In each well of the plate, $160 \mu \mathrm{L}$ of $1.5 \mathrm{mM}$ DTNB, $50 \mu \mathrm{L}$ of AChE $(0.22 \mathrm{U} / \mathrm{mL}$ eeAChE) or $50 \mu \mathrm{L}$ of BuChE $(0.12 \mathrm{U} / \mathrm{mL}$ eqBuChE) were incubated with $10 \mu \mathrm{L}$ of different concentrations of test compounds $(0.01-100 \mu \mathrm{M})$ at $37^{\circ} \mathrm{C}$ for $10 \mathrm{~min}$. After this period, acetylthiocholine iodide $(15 \mathrm{mM})$ or S-butyrylthiocholine iodide $(15 \mathrm{mM})$ as the substrate $(30 \mu \mathrm{L})$ was added, incubated for a further 10 minutes, and thereafter the absorbance was measured at a wavelength of $405 \mathrm{~nm}$ at different time intervals $(0,60,120$, and $180 \mathrm{~s}$ ). Five different concentrations of test compounds were used and the assays were run in triplicate. $\mathrm{IC}_{50}$ values were calculated as concentration of the compound that produces 50\% enzyme activity inhibition, using the Graph Pad Prism 6 software (San Diego, CA, USA).

\subsection{Anti-oxidant Assay}

Antioxidant scavenging activity was studied using 1,1-diphenyl-2-picrylhydrazyl free radical $\left(\mathrm{DPPH}^{+}\right)$[40, 41]. Various concentrations of test solutions in $20 \mu \mathrm{l} \mathrm{DMSO}$ were added to $180 \mu \mathrm{L}$ of $0.1 \mathrm{mM}$ solution of $\mathrm{DPPH}^{++}$in methanol. Neat methanol $(20 \mu \mathrm{l})$ was used as experimental control. After $30 \mathrm{~min}$ of incubation at room temperature, the reduction of free radical was measured by reading the absorbance at $517 \mathrm{~nm}$. Trolox ${ }^{\circledR}$ was used as reference standard. The scavenging activity of the samples corresponded to the intensity of the quenching of DPPH ${ }^{+}$. For statistical viability, the assay was performed three times with 3 readings for five different concentrations. $\mathrm{IC}_{50}$ values were calculated as concentration of the compound that produces 50\% enzyme activity inhibition, using the Graph Pad Prism 6 software (San Diego, CA, USA). 


\subsection{Cholinesterase Docking Studies}

\subsubsection{Acetylcholinesterase}

Modeling was performed using the Molecular Operating Environment (MOE 2015.10) software package. The X-ray crystal structure of the AChE in complex with bistacrine (code: 2CMF) was downloaded from the protein data bank (PDB) and loaded in the working environment. The bistacrine ligand was removed and the enzyme structure was checked for missing atoms, bonds and contacts. Hydrogens and partial charges were added using the protonate 3D application in MOE. The hybrid compounds were accurately drawn in ACD Chemsketch and saved as MDL mole files (V3000) and imported into the MOE database. The structures were energy minimized in implicit solvated environment under AMBER99 force field and docked into the active site of the protein. The binding site was defined with the conserved aromatic residues Trp279 and Trp84. All other parameters were left as default values. Finally, the conformation with the lowest docking score was selected for analysing the interactions between the AChE and the hybrid compounds.

\subsubsection{Butyrylcholinesterase}

Because no X-ray structure exists for eqBuChE, a homology model was used to rationalize the experimental data. The eqBuChE model was retrieved from the SWISS-MODEL Repository. This is a database of annotated threedimensional comparative protein structure models generated by the fully automated homology-modelling pipeline SWISS-MODEL. A putative three-dimensional structure of eqBuChE was created based on the crystal structure of hBuChE (PDB ID: 2PM8), these two enzyme exhibit 89\% sequence identity [32]. Proper bonds, bond orders, hybridization and charges were assigned and CHARMm force field was applied using MOE. The prepared protein was directly loaded into AutoDockTools (ADT; version 1.5.4), hydrogens were added and partial charges for proteins and ligands were calculated using Gasteiger charges. Flexible torsions in the ligands were assigned with the AutoTors module, and the acyclic dihedral angles were allowed to rotate freely. Docking calculations were performed with the program Autodock Vina [33]. Because VINA uses rectangular boxes for the binding site, the box center was defined and the docking box was displayed using ADT. All dockings were performed where a cube of 75 Á with grid points separated by $1 \AA$, was positioned over the active site of the protein $(\mathrm{x}=29.885 ; \mathrm{y}=-54.992 ; \mathrm{z}=58.141)$. Default parameters were used except num_modes, which was set to 40. The lowest docking-energy conformation was considered as the most stable orientation. Finally, the docking results generated were analyzed using MOE.

\section{CONCLUSION}

In this study, novel multi-target tacrine-trolox and tacrine-tryptoline hybrids were designed, synthesized and evaluated for ChE inhibition and free radical scavenging activity. All the hybrid compounds showed nanomolar to micromolar activity in $\mathrm{AChE}, \mathrm{BuChE}$ and free radical scavenging assays, some even better than their references compounds. The most potent are compounds $8 \mathbf{d}$ and 14. Compound $\mathbf{8 d}$ demonstrated good activity in all three assays with low SI for AChE / BuChE. Compound 14 showed the best dual cholinesterase inhibitor activity but with lower free radical scavenging activity. As evident in the bar graph (Fig. 6), 8d is the best lead molecule from this study as it demonstrated the best ability to inhibit $\mathrm{AChE}, \mathrm{BuChE}$ and act as a potent antioxidant. This result is supported by recently published work wherein the non-hepatoxicity of tacrine-trolox hybrids has been demonstrated [36]. Novel compound 14 showed promising activity for ChE inhibition and hybrid molecules in this series could also be further explored. Compounds 8d and $\mathbf{1 4}$ further showed interactions with both the CAS and PAS of AChE in docking studies and this indicate that 8a-d and $\mathbf{1 4}$ may be able to prevent cholinesterase induced A $\beta$ aggregation [19 - 22]. Overall, these results indicate that $\mathbf{8 d}$ and $\mathbf{1 4}$ as potential multifunctional agents for the treatment of AD, should be explored further. 


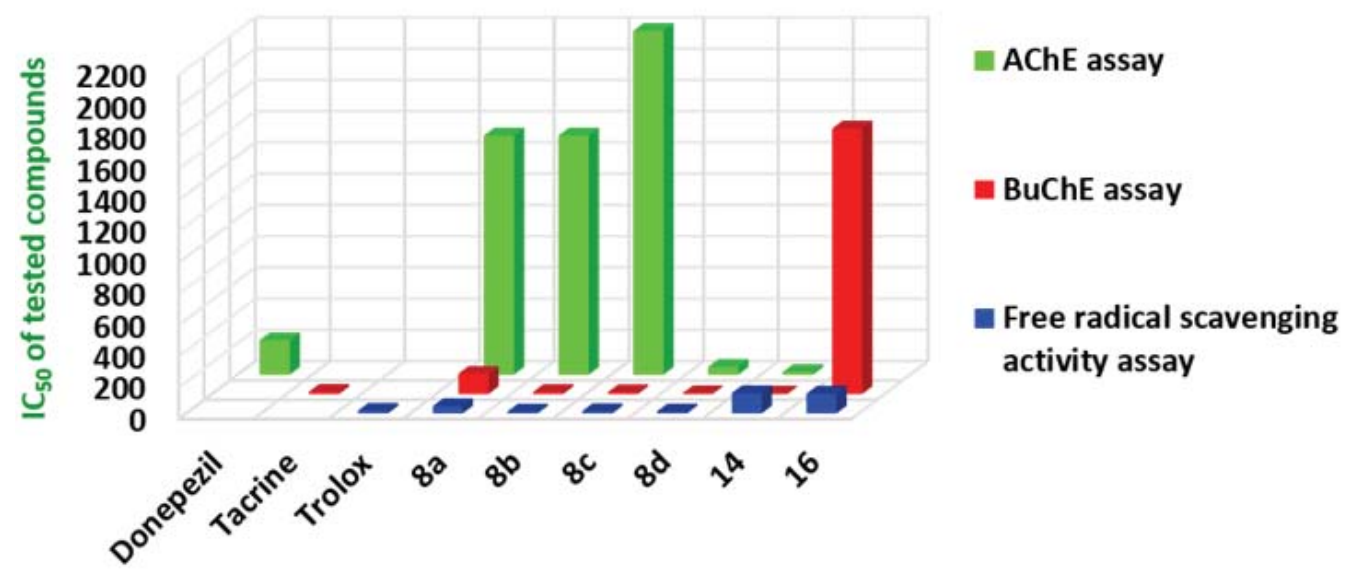

\section{Synthesized compounds and controls}

Fig. (6). Bar graph showing comparative study of $\mathrm{IC}_{50}$ values depicting the multifunctional ability of the synthesized compounds. Cholinesterase $\mathrm{IC}_{50}(\mathrm{nM})$; free radical scavenging activity $\mathrm{IC}_{50}(\mu \mathrm{M})$.

\section{CONFLICT OF INTEREST}

The authors confirm that this article content has no conflict of interest.

\section{ACKNOWLEDGEMENTS}

We are grateful for the financial support from the University of the Western Cape and The Medical Research Council of South Africa.

\section{REFERENCES}

[1] Goedert, M.; Spillantini, M.G. A century of Alzheimers disease. Science, 2006, 314(5800), 777-781. [http://dx.doi.org/10.1126/science.1132814] [PMID: 17082447]

[2] Silvestrelli, G.; Lanari, A.; Parnetti, L.; Tomassoni, D.; Amenta, F. Treatment of Alzheimers disease: from pharmacology to a better understanding of disease pathophysiology. Mech. Ageing Dev., 2006, 127(2), 148-157.

[http://dx.doi.org/10.1016/j.mad.2005.09.018] [PMID: 16278007]

[3] Duthey, B. Background paper 6.11: Alzheimer disease and other dementias. A Public Health Approach to Innovation, 2013 , pp: 1-74.

[4] Grimm, O.W.; Hartmann, T. Recent understanding of the molecular mechanisms of alzheimer's disease. J. Addict. Res. Ther., 2012.

[5] Skovronsky, D.M.; Lee, V.M.; Trojanowski, J.Q. Neurodegenerative diseases: new concepts of pathogenesis and their therapeutic implications. Annu. Rev. Pathol., 2006, 1, 151-170.

[http://dx.doi.org/10.1146/annurev.pathol.1.110304.100113] [PMID: 18039111]

[6] Crews, L.; Masliah, E. Molecular mechanisms of neurodegeneration in Alzheimers disease. Hum. Mol. Genet., 2010, 19(R1), R12-R20. [http://dx.doi.org/10.1093/hmg/ddq160] [PMID: 20413653]

[7] Capurro, V.; Busquet, P.; Lopes, J.P.; Bertorelli, R.; Tarozzo, G.; Bolognesi, M.L.; Piomelli, D.; Reggiani, A.; Cavalli, A. Pharmacological characterization of memoquin, a multi-target compound for the treatment of Alzheimers disease. PLoS One, 2013, 8(2), e56870. [http://dx.doi.org/10.1371/journal.pone.0056870] [PMID: 23441223]

[8] Simoni, E.; Daniele, S.; Bottegoni, G.; Pizzirani, D.; Trincavelli, M.L.; Goldoni, L.; Tarozzo, G.; Reggiani, A.; Martini, C.; Piomelli, D.; Melchiorre, C.; Rosini, M.; Cavalli, A. Combining galantamine and memantine in multitargeted, new chemical entities potentially useful in Alzheimers disease. J. Med. Chem., 2012, 55(22), 9708-9721.

[http://dx.doi.org/10.1021/jm3009458] [PMID: 23033965]

[9] Dias, K.S.; Viegas, C., Jr Multi-target directed drugs: a modern approach for design of new drugs for the treatment of Alzheimers disease. Curr. Neuropharmacol., 2014, 12(3), 239-255. [http://dx.doi.org/10.2174/1570159X1203140511153200] [PMID: 24851088]

[10] Wang, H.; Carlier, P.R.; Ho, W.L.; Wu, D.C.; Lee, N.T.; Li, C.P.; Pang, Y.P.; Han, Y.F. Effects of bis(7)-tacrine, a novel anti-Alzheimers agent, on rat brain AChE. Neuroreport, 1999, 10(4), 789-793.

[http://dx.doi.org/10.1097/00001756-199903170-00023] [PMID: 10208549]

[11] Rook, Y.; Schmidtke, K.U.; Gaube, F.; Schepmann, D.; Wünsch, B.; Heilmann, J.; Lehmann, J.; Winckler, T. Bivalent $\beta$-carbolines as potential multitarget anti-Alzheimer agents. J. Med. Chem., 2010, 53(9), 3611-3617.

[http://dx.doi.org/10.1021/jm1000024] [PMID: 20361801] 
[12] Kozurkova, M.; Hamulakova, S.; Gazova, Z.; Paulikova, H.; Kristian, P. Neuroactive multifunctional tacrine congeners with cholinesterase, anti-amyloid aggregation and neuroprotective properties. Pharmaceuticals, 2011, 4(2), 382-418. [http://dx.doi.org/10.3390/ph4020382]

[13] Szymański, P.; Skibiński, R.; Inglot, T.; Bajda, M.; Jończyk, J.; Malawska, B.; Mikiciuk-Olasik, E. New tacrine analogs as acetylcholinesterase inhibitors - theoretical study with chemometric analysis. Molecules, 2013, 18(3), $2878-2894$. [http://dx.doi.org/10.3390/molecules18032878] [PMID: 23459299]

[14] Halliwell, B. Free radicals and other reactive species in disease. eLS, 2001, 1-7.

[15] Radesäter, A.C.; Johansson, S.; Öberg, C.; Luthman, J. The vitamin-E analog trolox and the NMDA antagonist MK-801 protect pyramidal neurons in hippocampal slice cultures from IL-1 $\beta$-induced neurodegeneration. Neurotox. Res., 2003, 5(6), 433-442. [http://dx.doi.org/10.1007/BF03033173] [PMID: 14715447]

[16] Muñoz, F.J.; Opazo, C.; Gil-Gómez, G.; Tapia, G.; Fernández, V.; Valverde, M.A.; Inestrosa, N.C. Vitamin E but not 17ß-estradiol protects against vascular toxicity induced by $\beta$-amyloid wild type and the Dutch amyloid variant. J. Neurosci., 2002, 22(8), $3081-3089$. [PMID: 11943811]

[17] Herraiz, T.; González, D.; Ancín-Azpilicueta, C.; Arán, V.J.; Guillén, H. $\beta$-Carboline alkaloids in Peganum harmala and inhibition of human monoamine oxidase (MAO). Food Chem. Toxicol., 2010, 48(3), 839-845.

[http://dx.doi.org/10.1016/j.fct.2009.12.019] [PMID: 20036304]

[18] Frost, D.; Meechoovet, B.; Wang, T.; Gately, S.; Giorgetti, M.; Shcherbakova, I.; Dunckley, T. $\beta$-carboline compounds, including harmine, inhibit DYRK1A and tau phosphorylation at multiple Alzheimers disease-related sites. PLoS One, 2011, 6(5), e19264. [http://dx.doi.org/10.1371/journal.pone.0019264] [PMID: 21573099]

[19] Inestrosa, N.C.; Alvarez, A.; Pérez, C.A.; Moreno, R.D.; Vicente, M.; Linker, C.; Casanueva, O.I.; Soto, C.; Garrido, J. Acetylcholinesterase accelerates assembly of amyloid-beta-peptides into Alzheimers fibrils: possible role of the peripheral site of the enzyme. Neuron, 1996, 16(4), $881-891$. [http://dx.doi.org/10.1016/S0896-6273(00)80108-7] [PMID: 8608006]

[20] De Ferrari, G. V.; Canales, M. A.; Shin, I.; Weiner, L. M. A structural motif of acetylcholinesterase that promotes amyloid beta-peptide fibril formation. Biochemistry, 2001, 40, 10447-10457.

[21] Rees, T.M.; Berson, A.; Sklan, E.H.; Younkin, L.; Younkin, S. nBrimijoin, S.; Soreq, H. Memory deficits correlating with nAcetylcholinesterase splice shift and amyloid burden in doubly nTransgenic mice. Curr. Alzheimer Res., 2005, 2, 291-300. [http://dx.doi.org/10.2174/1567205054367847] [PMID: 15974894]

[22] Dinamarca, M.C.; Sagal, J.P.; Quintanilla, R.A.; Godoy, J.A. n Arrázola, M. S.; Inestrosa, N. C. Amyloid-beta-Acetylcholinesterasen complexes potentiate neurodegenerative changes induced by the nAbeta peptide. Implications for the Pathogenesis of Alzheimersn Disease. Mol. Neurodegener., 2010, 5,4 [http://dx.doi.org/10.1186/1750-1326-5-4] [PMID: 20205793]

[23] Talesa, V.N. Acetylcholinesterase in Alzheimers disease. Mech. Ageing Dev., 2001, 122(16), 1961-1969. [http://dx.doi.org/10.1016/S0047-6374(01)00309-8] [PMID: 11589914]

[24] Birks, J.; Harvey, R.J. Donepezil for dementia due to Alzheimers disease. Cochrane Database Syst. Rev., 2006, (1), CD001190. [PMID: 16437430]

[25] Loy, C.; Schneider, L. Galantamine for Alzheimers disease. Cochrane Database Syst. Rev., 2004, (4), CD001747. [PMID: 15495017]

[26] Birks, J.; Iakovidou, V.; Tsolaki, M. Rivastigmine for Alzheimers disease. Cochrane Database Syst. Rev., 2000, (4), CD001191. [PMID: 11034705]

[27] Greig, N.H.; Utsuki, T.; Ingram, D.K.; Wang, Y.; Pepeu, G.; Scali, C.; Yu, Q.S.; Mamczarz, J.; Holloway, H.W.; Giordano, T.; Chen, D.; Furukawa, K.; Sambamurti, K.; Brossi, A.; Lahiri, D.K. Selective butyrylcholinesterase inhibition elevates brain acetylcholine, augments learning and lowers Alzheimer beta-amyloid peptide in rodent. Proc. Natl. Acad. Sci. USA, 2005, 102(47), 17213-17218. [http://dx.doi.org/10.1073/pnas.0508575102] [PMID: 16275899]

[28] Giacobini, E. Cholinergic function and Alzheimers disease. Int. J. Geriatr. Psychiatry, 2003, 18(Suppl. 1), S1-S5. [http://dx.doi.org/10.1002/gps.935] [PMID: 12973744]

[29] Ellman, G.L.; Courtney, K.D.; Andres, V., Jr; Feather-Stone, R.M. A new and rapid colorimetric determination of acetylcholinesterase activity. Biochem. Pharmacol., 1961, 7, 88-95. [http://dx.doi.org/10.1016/0006-2952(61)90145-9] [PMID: 13726518]

[30] Schott, Y.; Decker, M.; Rommelspacher, H.; Lehmann, J. 6-Hydroxy- and 6-methoxy- $\beta$-carbolines as acetyl- and butyrylcholinesterase inhibitors. Bioorg. Med. Chem. Lett., 2006, 16(22), 5840-5843. [http://dx.doi.org/10.1016/j.bmcl.2006.08.067] [PMID: 16945529]

[31] Bajda, M.; Więckowska, A.; Hebda, M.; Guzior, N.; Sotriffer, C.A.; Malawska, B. Structure-based search for new inhibitors of cholinesterases. Int. J. Mol. Sci., 2013, 14(3), 5608-5632. [http://dx.doi.org/10.3390/ijms14035608] [PMID: 23478436]

[32] Kiefer, F.; Arnold, K.; Künzli, M.; Bordoli, L.; Schwede, T. The SWISS-MODEL Repository and associated resources. Nucleic Acids Res., 2009, 37(Database issue), D387-D392. 
[http://dx.doi.org/10.1093/nar/gkn750] [PMID: 18931379]

[33] Trott, O.; Olson, A.J. AutoDock Vina: improving the speed and accuracy of docking with a new scoring function, efficient optimization, and multithreading. J. Comput. Chem., 2010, 31(2), 455-461. [PMID: 19499576]

[34] Nishida, J.; Kawabata, J. DPPH radical scavenging reaction of hydroxy- and methoxychalcones. Biosci. Biotechnol. Biochem., 2006, 70(1), 193-202.

[http://dx.doi.org/10.1271/bbb.70.193] [PMID: 16428837]

[35] Karali, N.; Güzel, O.; Ozsoy, N.; Ozbey, S.; Salman, A. Synthesis of new spiroindolinones incorporating a benzothiazole moiety as antioxidant agents. Eur. J. Med. Chem., 2010, 45(3), 1068-1077. [http://dx.doi.org/10.1016/j.ejmech.2009.12.001] [PMID: 20045221]

[36] Nepovimova, E.; Korabecny, J.; Dolezal, R.; Babkova, K.; Ondrejicek, A.; Jun, D.; Sepsova, V.; Horova, A.; Hrabinova, M.; Soukup, O.; Bukum, N.; Jost, P.; Muckova, L.; Kassa, J.; Malinak, D.; Andrs, M.; Kuca, K. Tacrine-trolox hybrids: a novel class of centrally active, nonhepatotoxic multi-target-directed ligands exerting anticholinesterase and antioxidant activities with low in vivo toxicity. J. Med. Chem., 2015, 58(22), 8985-9003.

[http://dx.doi.org/10.1021/acs.jmedchem.5b01325] [PMID: 26503905]

[37] Chao, X.; He, X.; Yang, Y.; Zhou, X.; Jin, M.; Liu, S.; Cheng, Z.; Liu, P.; Wang, Y.; Yu, J.; Tan, Y.; Huang, Y.; Qin, J.; Rapposelli, S.; Pi, R. Design, synthesis and pharmacological evaluation of novel tacrine-caffeic acid hybrids as multi-targeted compounds against Alzheimers disease. Bioorg. Med. Chem. Lett., 2012, 22(20), 6498-6502. [http://dx.doi.org/10.1016/j.bmcl.2012.08.036] [PMID: 22981331]

[38] Lan, J.S.; Xie, S.S.; Li, S.Y.; Pan, L.F.; Wang, X.B.; Kong, L.Y. Design, synthesis and evaluation of novel tacrine-( $\beta$-carboline) hybrids as multifunctional agents for the treatment of Alzheimers disease. Bioorg. Med. Chem., 2014, 22(21), 6089-6104. [http://dx.doi.org/10.1016/j.bmc.2014.08.035] [PMID: 25282654]

[39] Savini, L.; Gaeta, A.; Fattorusso, C.; Catalanotti, B.; Campiani, G.; Chiasserini, L.; Pellerano, C.; Novellino, E.; McKissic, D.; Saxena, A. Specific targeting of acetylcholinesterase and butyrylcholinesterase recognition sites. Rational design of novel, selective, and highly potent cholinesterase inhibitors. J. Med. Chem., 2003, 46(1), 1-4.

[http://dx.doi.org/10.1021/jm0255668] [PMID: 12502352]

[40] Cotelle, N.; Bernier, J.L.; Catteau, J.P.; Pommery, J.; Wallet, J.C.; Gaydou, E.M. Antioxidant properties of hydroxy-flavones. Free Radic. Biol. Med., 1996, 20(1), 35-43. [http://dx.doi.org/10.1016/0891-5849(95)02014-4] [PMID: 8903677]

[41] Brand-Williams, W.; Cuvelier, M.E.; Berset, C. Leben.-Wiss, W. Use of a free radical method to evaluate antioxidant activity. Technol Food Sci Technol, 1995, 28, 25-30.

(C) Teponnou et al.; Licensee Bentham Open

This is an open access article licensed under the terms of the Creative Commons Attribution-Non-Commercial 4.0 International Public License (CC BY-NC 4.0) (https://creativecommons.org/licenses/by-nc/4.0/legalcode), which permits unrestricted, non-commercial use, distribution and reproduction in any medium, provided the work is properly cited. 